JAROSŁAW GARA

Akademia Pedagogiki Specjalnej

im. M. Grzegorzewskiej

Warszawa
Forum Pedagogiczne

$2017 / 2$

Wpłynęło: 05.01.2017

Zatwierdzono do druku: 12.05.2017

DOI: $10.21697 /$ fp.2017.2.11

\title{
FENOMENOLOGICZNA KATEGORIA ŚWIATA ŻYCIA CODZIENNEGO JAKO PRZESŁANKA EKSPLIKACJI SENSÓW EDUKACJI
}

Streszczenie: Sformułowany problem opiera się na próbie przybliżenia trzech zasadniczych zagadnień, wyrażonych $\mathrm{w}$ trzech pytaniach i przynależnych im perspektywach problemowych: 1. Jakie są podstawowe przesłanki fenomenologicznych nastawień badawczych?; 2. Jak jest rozumiana fenomenologiczna kategoria świata życia codziennego?; 3. W jaki sposób fenomenologiczna kategoria świata życia codziennego pozwala na ujmowanie i rozjaśnianie sensów edukacji? Fenomenologia świata życia codziennego, rozwijana przez Edmunda Husserla w ostatnim okresie jego twórczości, opiera się na założeniu, że ów świat przeżywany jest właściwym i nieredukowalnym punktem wyjścia dla nauk humanistycznych i społecznych. Jest to bowiem wspólny świat codziennych sytuacji i praktycznego działania. W tym też kontekście odnoszę się do fenomenu edukacyjnych preliminariów i imponderabiliów oraz rozpatruję kwestie sensotwórczości doświadczenia paradoksalności, aporetyczności i dialektyczności rozwoju człowieka. To zaś daje podstawę do ujmowania tytułowych sensów edukacji jako swoistego egzystencjalnego doświadczenia odysei.

Słowa kluczowe: fenomenologia świat życia codziennego, filozofia edukacji, egzystencjalne aporie, myślenie paradoksami, edukacja jako odyseja

„Uważność poświęcona codzienności, kamień węgielny naszego projektu praktyki fenomenologicznej, czerpie inspirację właśnie z postawy dziecka. [...] Kiedy dziecko jest tutaj, jest w pełni obecne; kiedy jest «rozproszone», to dlatego, że w rzeczywistości jest w pełni obecne przy tym, co go rozprasza. Wygląda na to, że dziecko jest zawsze obecne w pełni przy tym, co robi: na tym polega jego zasadniczy sposób bycia [...] Zatem przeżywanie chwili obecnej niekoniecznie jest byciem-naprawdę-tu, dokładnie i intensywnie może to być chwilowe zapomnienie się i odkrywanie z nagła, że się «było gdzie indziej»" (Depraz 2010, s. 270, 269).

„Świat nie jest dla nas zbiorem czy systemem kategorii, lecz jednolitym schematem, w którym kategorie mają swoje miejsce. Schemat ten nie jest możliwy 
bez wypełniających go poszczególnych realnych rzeczy; sam w sobie nie istnieje. [...] świat, jak widzieliśmy, jest w procesie nieustannego dziania się i tylko jego podstawowe wymiary pozostają stałym kośćcem wśród dokonujących się zmian. [...] w naszym ujęciu świat nie jest postulatem ani celem, za którym doświadczenie podąża, lecz jakąś wstępną całością, na której gruncie ono się rozwija” (Patočka 1986, s. 70).

Tytułowy problem ma charakter przekrojowy, a ujmowany w perspektywie popularyzatorskiej wymaga przybliżenia co najmniej trzech zagadnień, wyrażonych w trzech pytaniach i przynależnych im perspektywach problemowych: 1. Jakie są podstawowe przesłanki fenomenologicznych nastawień badawczych?; 2. Jak jest ujmowana i dookreślana kategoria świata życia codziennego (niem. Lebenswelt) ${ }^{1}$ ?; 3. W jaki sposób fenomenologiczna kategoria świata życia codziennego pozwala na ujmowanie i rozjaśnianie sensów edukacji? Odpowiedź na dwa pierwsze pytania oparta będzie na rekonstrukcji studialnej przedmiotowego pola badań, a odpowiedź na ostatnie pytanie - po zaprezentowaniu pedagogicznych recepcji kategorii świata życia codziennego z perspektywy specyficznych fenomenologicznych momentów edukacji - odsyłać będzie do autorskich analiz przedmiotu zainteresowania, wyrażonego w tytułowym problemie. Tym samym w ramach aplikacyjnego ujmowania i rozjaśniania sensów edukacji wyróżniony zostanie: 1. Problem edukacyjnych preliminariów i imponderabiliów; 2. Problem aporetyczności doświadczenia rozwoju człowieka; 3. Problem paradoksalności edukacyjnego doświadczenia sensotwórczości i w końcu 4. Problem doświadczenia aporii sensu swojskości i zadomowienia. Ostatni problem będzie heurystycznym otwarciem

1 Kategoria Lebenswelt zarówno w polskich tłumaczeniach dzieł Edmunda Husserla, jak i w specjalistycznej literaturze przedmiotu najczęściej oddawana jest przez terminy: „świat życia codziennego”, „świat przeżywany” czy „świat życia”. Przyjmuję jednak, że określenie „świat życia codziennego" jako terminus technicus w sposób najpełniejszy wyraża filozoficzne znaczenie tegoż terminu. Tym też określeniem będę się zasadniczo posługiwał, choć nie wykluczam zasadności stosowania pozostałych określeń. Kategoria Lebenswelt, wprowadzona przez twórcę fenomenologii w ostatnim okresie jego twórczości, wytycza też ostatni punkt zwrotny - „przewrót kopernikański” - jego myśli, i powinna być ona odróżniana od pojęć, którymi posługiwał się w różnych okresach i w różnym stopniu, mianowicie: Welt („świat”), Umwelt („świat otaczający”), czy Lebensumwelt („przeżywany świat otaczający”). Choć oczywiście pojęcia te znaczą drogę Husserla do samej Lebensweltphilosophie (Krasnodębski, Nellen 1993, s. 9). Warte odnotowania jest również i to, że podejmując w tym miejscu zagadnienia filozofii świata życia codziennego, pomijam całkowicie problem sporu wokół transcenentalnego idealizmu Husserlowskiej fenomenologii (kwestii transcendentalnego ego, transcendentalnej epoché, transcendentalnej subiektywności). Tę warstwę jego filozofii uznaję bowiem za poddaną gruntownej i przekonującej krytyce wśród samych fenomenologów jeszcze za życia E. Husserla. Podzielam też w tym względzie hermeneutyczne przekonanie, że na niekwestionowane zdobycze Husserlowskiej fenomenologii należy patrzeć z pominięciem kwestii transcendentalnego idealizmu (Ricoeur 1996; Ingarden 1970; Rolewski 1999). 
sensu largo horyzontu dla pojmowania edukacji w jej sensotwórczych egzystencjalnie funkcjach jako swoistej odysei ${ }^{2}$.

\section{Fenomenologiczne nastawienia badawcze}

Jednym z podstawowych założeń fenomenologicznych nastawień badawczych jest to, że istnieniu specyficznych, bo idealnych przedmiotów, z konieczności musi odpowiadać specyficzny sposób ich poznawczego ujmowania (poznania a priori, apriorycznego wglądu w istotę). Swoistość tych przedmiotów (fenomenów) i sposobów ich poznawczego ujmowania wyartykułowana została przez Edmunda Husserla m.in. w takich określeniach, jak: „fenomenologiczna treśc”, „dane fenomenologiczne”, „fenomenologiczny punkt widzenia”, „fakt fenomenologiczny”, "pole analizy fenomenologicznej” (Husserl 20ooa, s. 77, 203, 211, 345, 436, 551), „fenomenologiczne rozjaśnianie/ujaśnienie znaczenia” (Husserl 20oob, s. 133, 239,), „fenomenologiczny rdzeń”, czy „fenomenologiczna analiza” (Husserl 1989, s. 25, 35).

Metodycznie ustrukturyzowany zamysł fenomenologicznych nastawień (postawy fenomenologicznej) jest więc naturalną konsekwencją zarówno rozumienia samej kategorii doświadczenia, jak i kategorii fenomenologicznego przedmiotu badań. Ambicją fenomenologicznego badania nie jest rozstrzyganie o faktycznym, tzn. aktualnym i jednostkowym istnieniu lub nieistnieniu czegoś tak, a nie inaczej, lecz o możliwości lub niemożliwości, konieczności lub niekonieczności bycia tego czegoś w ogóle (Husserl 2ooob, s. 196). W ten sposób sens metody fenomenologicznej - na co zwraca uwagę Krzysztof Michalski - wyraża się w tym, że jest ona „analizą i opisem samego procesu zjawiania się czegoś, badaniem stosunku różnych perspektyw i sposobów prezentacji tego, co w nich dane" (Michalski 1998, s. 17).

Mówiąc o fenomenologicznych nastawieniach, zakładamy więc zarówno określoną postawę, jak i metodę, co wyraża się w „fenomenologicznym spojrzeniu” na określone rzeczy oraz $\mathrm{w}$ „fenomenologicznym nastawieniu” względem tychże rzeczy. Sam Husserl używał określenia „postawa duchowa”. W podobny sposób inni fenomenolodzy podkreślali swoistość owych nastawień. I tak Roman Ingarden mówił o „duchowym spojrzeniu” (Ingarden 1963, s. 313), Adolf Reinach o „spojrzeniu” $\mathrm{i}$,nastawieniu” fenomenologicznym (Reinach 2005, s. 117), Max Scheler o „postawie duchowego patrzenia”, w której „można zobaczyć lub przeżyć coś, co bez niej pozostaje ukryte” (Scheler 1975, s. 131), a Hedwig Conrad-Martius o „duchowym

$2 \mathrm{~W}$ takim ustrukturyzowaniu tytułowy problem został zaprezentowany jako odczyt w trakcie posiedzenia Zespołu Pedagogiki Ogólnej PAN w Warszawie, 4 listopada 2016 roku. Tak zakreślona problematyzacja oparta jest też na wybranych fragmentach i związanych z nimi wątków lub aspektów, publikowanych już lub czekających na publikację wyników badań oraz związanych $\mathrm{z}$ nimi autorskich analizach $\mathrm{w}$ odniesieniu do przedmiotowego pola zainteresowania. Tekst stanowi zatem spójną w warstwie swego zamysłu reasumpcję, syntetyczną i całościową prezentację obszerniejszych i rozleglejszych badań, towarzyszących im ustaleń oraz konceptualizacji teoretycznych (Gara 2015; 2016; 2017a; 2017b). 
organie”, jako warunku adekwatnego „nakierowania się” na rzecz poznania w jej istotowych intelligibilliach (Conrad-Martius 1986, s. 279). Owo doświadczenie, o którym tu mowa - jak ujmuje to Władysław Stróżewski - „to nie bierne «gapienie się»", lecz aktywne przystosowanie się do doświadczanego przedmiotu, co jest możliwe dzięki intencjonalnej strukturze doświadczającej świadomości. Ta intencjonalna aktywność musi być odpowiednio kierowana i może być modyfikowana w celu spełnienia zadania, jakie wyraża hasło "powrotu do rzeczy samej»" (Stróżowski 1989, s. 83). Celem tak pojętych nastawień jest wyrobienie „zdolności patrzenia” i „ostateczne ujaśnienie” przedmiotu poznania.

Odwołując się do wczesnej fenomenologii jako „uniwersalnej ontologii” (tzw. fenomenologii „rdzennej” lub ejdetycznej), wyrastającej z impulsów i inspiracji Badań logicznych E. Husserla, metodologię badań istotnościowych ująć można przez pryzmat dwóch procedur postępowania badawczego: abstrakcji ideującej (ideacji, refleksji ideującej) oraz wariacji imaginacyjnej (uzmienniania, refleksji uzmienniającej) (Rożdżeński 1998; Zaner 1975). W myśleniu ideacyjnym, wyeksponowana jest pewna ogólna, „duchowa” dyspozycja, aby „widzieć” coś jako pewną wyodrębniającą się całość na tle horyzontu innych rzeczy, zjawisk i procesów, zaś w myśleniu uzmienniającym mamy do czynienia z wyeksponowaniem samej techniki, służącej „wyostrzeniu” owego „widzenia” (wglądu), tak by ujmować porównywać i rozróżniać - części składowe na tle horyzontu całości samej rzeczy, do której przynależą.

Mówiąc o ideacji, mamy na myśli naoczne uchwytywanie istoty i sensu tego, co ogólne. W ten sposób myślenie ideujące, jako swoista procedura poznania, służyć ma ujęciu jakości idealnych, tzn. takich, którym właśnie przysługuje istnienie ogólne (Stróżowski 1989, s. 180-181). Ideacja jest więc aktem „pomyślenia” (tzn. wyobrażeniowego „zobaczenia”, „uchwycenia”, „wyróżnienia”) czystych jakości species (tzn. określonego rodzaju, gatunku czy ogólnej idei) oraz kategorialnych stanów rzeczy, które podlegają prawom kategorialnym i o których możemy orzekać w ogólności (Husserl 20oob, s. 194 226) (np. „człowiek w ogóle”, „równoległobok w ogóle”, „przedmiot w ogóle”, „proces w ogóle”) (Ingarden 1971, s. 267, 280, 287). W aktach abstrakcji ideującej próbujemy zatem uchwycić to, co uogólnione, np. „zieleń w ogóle”. Szczególność tej operacji „myślenia” (wyobrażeniowego „widzenia”) - jak zauważa to Roman Ingarden - wyraża się tym samym w takim pokierowaniu naszej uwagi, aby skoncentrować się „na samej «zieleni», jej jakości, jej nasyceniu, i wreszcie na tym, jaka ona jest, nie potwierdzając niejako tego, że oto tu, teraz występuje coś jednostkowego w naszym polu widzenia" (Ingarden 1971, s. 287). Tym samym idealne jakości, tzn. to, co ogólne i uniwersalne, można pojmować jako swoisty „rdzen” ponadempirycznej jedności - identyczności tego, co pozostaje zawsze niezmienne w kontekście „mnogości możliwych przypadków jednostkowych” (Husserl 2006, s. 130). W ten sposób problem zaistnienia lub występowania czegoś w sposób faktyczny, zupełnie nie jest brany pod uwagę, w przeciwieństwie do podejścia empirycznego, w którym stanowi to właśnie punkt 
wyjściowy. W poznaniu fenomenologicznym kluczowe jest bowiem wyodrębnienie „momentów atrybutywnych" (Husserl 2000a, s. 281), w poznaniu zaś empirycznym chodzi o odnotowanie „momentów faktycznych”.

\section{Fenomenologia świata życia codziennego}

Ludzka świadomość w swych intencjonalnych typach odniesień to życie podmiotu "głęboko zanurzonego w pierwotnym świecie" (Lyotard 2000, s. 95). Struktura doświadczenia zawsze opiera się tu na oczywistościach przedpredykatywnych i to ta sfera stanowi substrat wszelkich innych doświadczeń oraz poczynań człowieka, fundując wszelkie inne typy oczywistości o charakterze predykatywnym, np. oczywistości związane z twierdzeniami i konceptualizacjami naukowymi. Świat przeżywany $^{3}$ jawi się więc jako „zanurzenie” w pierwotnym, przedteoretycznym doświadczeniu bezpośrednio danej rzeczywistości. Owo „zanurzenie” w świecie życia codziennego stanowi punkt wyjścia „zaszyfrowywania” (kodowania, zakrywania, rozmywania, zacierania), jak i „rozszyfrowywania” (odkodowywania, odkrywania, precyzowania, uwyraźniania) sensu i znaczenia zarówno tego, co nas otacza i w czym uczestniczymy oraz tego, co bezpośrednio dotyczy zagadkowości

3 Przywoływana tu kategoria świata życia codziennego oczywiście związana jest z filozoficznym typem problematyzacji i filozoficznym „przewrotem kopernikańskim” w tym względzie. Warte jest to tym bardziej podkreślenia, że współcześnie mamy do czynienia z upowszechnianiem się takich perspektyw badawczych, jak: historia codzienności, socjologia codzienności, antropologia codzienności czy ekologia codzienności (Tarkowska 200o, s. 75-92). Rzadko jednak w rodzimej pedagogice spotykamy się z gruntownymi odniesieniami do filozofii Lebensweltu - filozofii świata życia codziennego. Choć już w latach 6o. XX wieku autorzy, klasycznej skądinąd dziś pracy, stwierdzali: „Za najodpowiedniejszą metodę wyjaśniania podstaw wiedzy życia codziennego uważamy analizę fenomenologiczną" (Berger, Luckmann 200o, s. 32). Warto zauważyć również, że początkowo, po śmierci Husserla w 1938 roku, zanim fenomenologia świata życia codziennego zaczęła się pojawiać $w$ dyskusjach filozoficznych, najpierw musiała ona, jak ujęli to Zdzisław Krasnodębski i Klaus Nellen, „udać się na podwójne wygnanie - przenieść się do innego kraju i innej dyscypliny". Tym innym krajem były Stany Zjednoczone Ameryki, dyscypliną - socjologia, a głównymi badaczami - Alfred Schütz i Aron Gurwitsch, uczniowie Husserla. I to dzięki ich badaniom ponownie i w szerszej skali rozbudzone zostało zainteresowanie samych filozofów Husserlowską fenomenologią Lebensweltu. I choć w tym samym czasie również Jan Patočka, czeski uczeń E. Husserla, podjął zaawansowane studia filozoficzne nad tą problematyką, to jednak jego wkład w tym względzie długo pozostawał nieznany i bez szerszego odbioru (Krasnodębski, Nellen 1993, s. 11). Ostatnia uwaga, którą jestem winny w tym miejscu, związana jest $\mathrm{z}$ zarysem fenomenologii świata życia codziennego, zawartym $\mathrm{w}$ tym rozdziale, a ujętym wraz z jej uściśleniami i eksploracyjnymi kierunkami rozumowania kontynuatorów Husserlowskiej Lenensweltphilosophie. Nie jest to zatem tylko rekonstrukcja zasadniczego punktu wyjścia, jakim był namysł twórcy fenomenologii nad tą problematyką. Odnoszę się bowiem w równym stopniu do interpretacji, reinterpretacji i autorskich ustaleń tych, którzy ów problem w nawiązaniu do E. Husserla i przewodnich impulsów jego filozofii podejmowali/ rozważali. 
nas samych - tego, czym byliśmy, jesteśmy lub będziemy (Lyotard 20oo, s. 83). W ten sposób „życie naturalne” - jak stwierdza Husserl - możemy „scharakteryzować jako naiwne otwarcie się na świat, który jako uniwersalny horyzont zawsze jest w pewien sposób obecny dla świadomości, ale nietematycznie. Tematycznie [obecne] jest to, na co [świadomość] się kieruje. Życie przytomne zawsze jest kierowaniem się na to lub owo, jest skierowane na coś jako na cel lub środek, jako coś ważnego lub nieważnego, interesującego lub obojętnego, prywatnego lub publicznego, na potrzebę codzienną lub nowo powstającą" (Husserl 1993, s. 26; por. Lyotard 2000, s. 27-29). Dlatego też nieredukowalnym punktem wyjścia dla nauk humanistycznych i społecznych jest właśnie „nastawienie naturalne”, określane doświadczeniem świata życia codziennego. I to w tym świecie „znajduje się - argumentuje filozof i może się odnaleźć w przytomnym życiu każdy, a więc i początkujący naukowiec-humanista, zanim jeszcze rozpocznie swe naukowe czynności i zamierzenia. Znajduje się w świecie, który go otacza, który przejawia mu się raz tak, raz inaczej, dostarcza mu raz takich, raz innych motywacji, w świecie, któremu się przygląda, któremu się przysłuchuje itd., który w ogóle na różne sposoby praktycznie go określa i któremu w tej praktyce nadaje on coraz to nowe oblicza. Do tego świata należy także on sam i ludzie, z którymi się kontaktuje; czy to jako z obiektami tej praktyki, czy też podobnymi doń jej podmiotami; współdziała wtedy z nimi, ale także współ-widzi, współ-słyszy - naturalnie te same należące do otaczającego świata rzeczy, zwłaszcza te, które w praktyce «wchodzą w grę» ze względu na jej uwspólnocony praktyczny kierunek" (Husserl 1993, s. 81).

Postawa naturalna człowieka znajduje bowiem swój intersubiektywny odpowiednik w postawie naturalnej innych ludzi, którzy w podobny, choć nie identyczny sposób doświadczają tego wspólnego świata. Z tego też względu postawa naturalna, odnosząc się do świata życia, który jest dany jako wspólny dla wielu, potencjalnie wszystkich podmiotów doświadczenia w danym czasie i miejscu, jest postawą świadomości potocznej (Berger, Luckmann 2000, s. 37). Choć perspektywa przeżywania świata przez jednych nie pokrywa się w sposób prosty z perspektywą innych podmiotów doświadczenia, ponieważ hipotetycznie lub też faktycznie „Moje «tutaj» jest ich «tam». Moje «teraz» wcale nie pokrywa się całkowicie $\mathrm{z}$ ich «teraz». Moje zamiary różnią się od ich zamiarów, a mogą nawet popaść z ich zamiarami w konflikt. Mimo to wiem, że żyję z nimi we wspólnym świecie" (Berger, Luckmann 2000, s. 37). Nastawienie naturalne odsyła nas zatem do problemu doświadczenia świata życia codziennego - świata codziennych sytuacji i praktycznego działania, świata w którym ludzie spotykają innych ludzi, rodzą się i umierają, uczą się i pracują (Patočka 1993, s. 42). Jest to doświadczenie „naiwności życia” w świecie, który w sposób najbardziej pierwotny nas otacza i „zawsze w jakiś sposób jest nam już znany" (Święcicka 1993, s. 104). To, co przedstawia się i uobecnia jako hic et nunc, w sposób napierający, śpieszny i bezpośredni stanowi realissimum naszej świadomości, stąd świat życia codziennego doświadczany jest „w stanie czujności (Berger, Luckmann 2000, s. 35) i „napięcia świadomości” (Berger, Luckmann 2000, s. 34). 
Ten „stan czujnego istnienia w życiu codziennym i czujnego postrzegania rzeczywistości życia codziennego uznaję za normalny i zrozumiały sam przez się, konstytuuje on moją postawę naturalną" (Berger, Luckmann 200o, s. 35). Dlatego też jest to świat, w który jesteśmy uwikłani, a co za tym idzie, zaangażowani w jego „historię i w intersubiektywność" - zanurzeni w dziejowości, w której doświadcza się wymiany i komunikacji, form językowych i społecznych.

Powrót do źródłowych doświadczeń świata życia codziennego umożliwia postawienie tym samym pytania o „historycznie pierwotny sens” (Schütz 1989, s. 121) oraz „źródłową oczywistość tradycji oddziałującej przez stulecia” (Schütz 1989, s. 119) - jest to pytanie o dzieje nawarstwiania się wszystkich przeżyć, składających się na faktyczną, bo uwarunkowaną egzystencjalnie, konstytucję strumienia naszej świadomości (Schütz 1989, s. 112-113; zob. także Schütz 1966, s. 120-124). Tak więc jest to świat, „w którym żyjemy i w którym zajmujemy się poznawaniem i sądzeniem, świat, z którego pobudza nas wszystko, co staje się substratem możliwych sądów, jest nam zawsze z góry dany jako przeniknięty osadem tworów logicznych; nie jest nam nigdy dany inaczej niż jako świat, w którym my sami lub inni, pozwalający nam przejmować ich doświadczenie dzięki komunikacji, nauce i tradycji, już działamy, wydając sądy logiczne i poznając. Dotyczy to nie tylko typowo określonego sensu, z jakim każdy przedmiot stoi przed nami jako znajomy, w horyzoncie typowej zażyłości, lecz także zarysu horyzontu, sensu, z jakim jest on nam w ogóle z góry dany jako przedmiot możliwego poznania, jako dający się w ogóle określić" (Husserl 2013, s. 50). W takim świecie ratio nie uwidacznia się wprost, ponieważ jest ukryte i trzeba je dopiero wydobyć „za pomocą hermeneutycznych procedur i metod, wykrywających rozumność przede wszystkim tam, gdzie najmniej jej się można było spodziewać: w lebensweltowej dóxa" (Rolewski 1999, s. 222). Świat życia codziennego jest zatem „fundamentem wszelkiego sensu” oraz określa warstwę najbardziej pierwotnego zapoczątkowania doświadczenia ludzkiego (Lyotard 2000, s. 175). W tym znaczeniu kategoria ta stanowi odkrycie tego, co zostało zapomniane i pogardzone przez teoretyczne roszczenie „rozumu naukowego". Sens świata życia codziennego, który jest zastany przez człowieka jako dany z góry, jest jednak „wytworem subiektywnym, jest produktem (Leistung) doświadczającego, przednaukowego życia. W tym to życiu buduje się sens świata i jego rangę jako czegoś istniejącego (Seinsgeltung), i to tego świata, który dla aktualnie doświadczającego podmiotu rzeczywiście i w sposób obowiązujący uchodzi za istniejący" (Husserl 1976, s. 104). Ów świat określa więc ramy naszego, subiektywnego świata, który jest przez nas doświadczany i przeżywany, z którego wyłaniają się i do którego skierowane są wszystkie nasze działania. „Cofanie się do świata doświadczenia - konstatuje fenomenolog - jest cofaniem się do «świata życia», tzn. do świata, w którym już żyjemy i który stanowi podłoże wszelkiego dokonania poznawczego i wszelkiego ujęcia naukowego" (Husserl 2013, s. 49).

Wiedza dotycząca świata życia codziennego określana jest motywem pragmatycznym, a zatem ma charakter praktyczny i zróżnicowana jest ze względu na sfery 
bliskości i oddalenia, tak w znaczeniu czasowym, jak i przestrzennym (Berger, Luckmann 200o, s. 36). Z tego punktu widzenia jest to wiedza podporządkowana właściwej sobie, immanentnej doświadczeniu świata życia codziennego, zasadzie istotności (Berger, Luckmann 2000, s. 64). „Moja wiedza życia codziennego pełni rolę narzędzia, które wycina ścianę w puszczy oraz, w miarę tej czynności, rzuca snop światła na to, co znajduje się tuż przede mną i w bezpośrednim sąsiedztwie; wokół ścieżki nadal jednak trwa mrok" (Berger, Luckmann 2000, s. 65). Taki świat uobecnia się w moim doświadczeniu per se, dlatego też „jeżeli chcę się przeciwstawić tej jego autoproklamacji, muszę podjąć świadomie zamierzony i wcale niełatwy wysiłek" (Berger, Luckmann 2000, s. 38). W ten sposób obowiązywalność takiej wiedzy przyjmowana jest również per se, „dopóki nie pojawi się coś, co ją zakwestionuje, to znaczy dopóki nie powstanie problem, którego nie pozwoli mi rozwiązać. Tak długo, jak długo moja wiedza służy mi zadowalająco, jestem najczęściej gotów zawiesić dotyczące jej wątpliwości" (Berger, Luckmann 200o, s. 63-64). Potrzeba zatem „szczególnych motywów - stwierdza Husserl - by ten, kto żyje w takim świecie, dokonał przestawienia i doszedł do tego, aby tematem uczynić jakoś sam świat, aby zainteresować się nim na stałe" (Husserl 1993, s. 26-27). Cokolwiek wydarza się lub dzieje w horyzoncie tego świata, w sposób nieredukowalny dotyczy nas samych i „stanowi w nim byt tego samego rodzaju, co sam ten świat” (Husserl 1976, s. 107). Świat naszej codzienności jest czasowo-przestrzenny, doświadczamy go zaś w sposób całkowicie przedteoretyczny - przednaukowy i pozanaukowy, w postaci przedpredykatywnych oczywistości doświadczenia. Natrafiamy w nim na rzeczy („kamienie, zwierzęta, rośliny”), ludzi oraz wytwory ludzkiej aktywności i doświadczamy ich jako zastanych lub takich, o których wiemy, że wykraczają wprawdzie poza aktualne doświadczenia, ale „które mogą być dane w doświadczeniu” (Husserl 1976, s. 108). Dlatego też spójność tego świata, ,jako jedności ogółu tego, co podpada pod doświadczenie w ogóle", nie opiera się tylko i wyłącznie na faktycznym (w znaczeniu empirycznym) doświadczeniu, ale również na hipotetycznym doświadczeniu, „jakie może sobie przedstawić fantazja”, ponieważ „jest to byt nawet jeśli nie rzeczywistego, to w każdym razie możliwego świata" (Husserl 2013, s. 48), oraz „horyzont rzeczy odkrywalnych, nawet jeśli jeszcze nieznanych” (Husserl 2013, s. 248).

Rzeczywistość świata życia codziennego określana jest więc tym, co powstaje w sferze naszych myśli lub działania, a zatem w tym, co zamierzamy zrobić lub już zrobiliśmy. I to dzięki takim właśnie myślom i działaniom ów świat konstytuuje się i trwa jako rzeczywisty (Berger, Luckmann 200o, s. 32). Źródła wszelkiej rzeczywistości - stwierdza Alfred Schütz - mają charakter subiektywny. Wszystko to, co pobudza i stymuluje nasze zainteresowanie, jest realne" (Schütz 2012, s. 17). W ten sposób świat życia codziennego, jako „uniwersalne podłoże” przedpredykatywnych oczywistości doświadczenia, stanowi podstawę ufundowania wszelkich oczywistości predykatywnych (Husserl 2013, s. 48-49), ponieważ jest to „intersubiektywny świat zdrowego rozsądku", który jako taki w warstwie swych subiektywnych stanów 
rzeczy i procesów oraz przynależnych im znaczeń może być dopiero poddawany próbom obiektywizacji (Berger, Luckmann 2000, s. 32).

\section{Edukacyjne preliminaria i imponderabilia}

Edukacyjne preliminaria i imponderabilia określone będą tu poprzez wyodrębnienie edukacyjnych fenomenów iluminacji, sensu, atmosfery, obecności, tajemnicy, inności, wrażliwości. Ich pierwotny, a zarazem trudno mierzalny, choć realnie wpływający na bieg oddziaływań edukacyjnych charakter, jest bowiem ściśle związany z doświadczeniem świata życia codziennego. Egzemplifikacją rozjaśniania poszczególnych fenomenów edukacji są wybrane recepcje filozofii świata życia codziennego oraz próby jej implementacji, z pozycji fenomenologiczno-hermeneutycznego profilu badań pedagogicznych.

\section{Fenomen iluminacji versus platońska jaskinia cieni}

Friedrich Copei, nawiązując do pojęcia sokratejskiej maieutyki, podjął próbę dookreślenia doświadczenia „twórczych momentów” procesu kształcenia. Są to takie momenty, które budzą w uczniu poznanie i zrozumienie czegoś dotychczas niedostrzeganego i nierozumianego. Mimo że zaistnienie tych momentów nie do końca można metodycznie zaplanować, to jednak dzięki nim uczeń doznaje swoistej iluminacji, tak iż rozbłyskuje w jego świadomości poznanie lub zrozumienie czegoś nowego (Copei 1969, s. 20-21). „Twórcze momenty”, podobnie jak sokratejska maieutyka, uaktywniają coś w człowieku i pozwalają wydobyć to na światło dzienne, jako uświadomione i zrozumiane, wyprowadzając to niejako z platońskiej jaskini cieni. Kształcenie przybiera tu zatem postać wciągania w sokratejski dialog majeutycznego problematyzowania rzeczywistości. Sam rozbłysk poznania jest więc wynikiem zarówno intuicyjnego, jak i dyskursywnego myślenia. Dochodzenie do zrozumienia czegoś jest pochodną zarówno wcześniejszych doświadczeń, jak i umiejętności stawiania określonych pytań. Pytania zawsze bowiem naprowadzają nas na rzecz poznania, problematyzując ją i odsłaniając określone sensy lub rozwiązania. Pytania inicjują i wywołują egzystencjalny rozbłysk poznawczej iluminacji (Meyer-Drawe 1997, s. 158).

Fenomen sensu versus „żywot ślimaka w muszli”

Martinus Jan Langeveld podejmował analizy problemu doświadczania i przeżywania przez dziecko konkretnych sytuacji wychowawczych, jak również roli i odpowiedzialności dorosłych w kreowaniu tychże sytuacji (Langeveld 1984, s. 217, 221-223). Owe konkretne sytuacje określają przestrzeń doświadczenia świata życia codziennego, która powinna być przedmiotem zainteresowań antropologicznych, bo odkrywających wiedzę o człowieku (dziecku) i jego relacjach ze światem 
(Ablewicz 2003, s. 73-74). Dziecko nigdy nie jest jak „ślimak w muszli”, ponieważ zawsze jest wiedzione ruchem „ku”, szukając kontaktu z otaczającym go światem i tym, co w nim można odnaleźć. Ów spontaniczny ruch „ku” jest pochodną „naturalnego założenia” (intuicji, wiary), które towarzyszy dziecku, a zgodnie z którym to, co znajduje się w otaczającym świecie, ma jakiś sens, posiada jakieś znaczenie. „Świat dziecka” nigdy nie jest jednak prostym odzwierciedleniem „świata dorosłych", ponieważ odsłania takie wymiary i znaczenia, których nie można wydedukować ze „świata dorosłych”. Stąd dorośli powinni „wchodzić (wczuwać się) w świat”, w którym żyje dziecko - odkrywać go, uczyć się go, postrzegać go jego własnymi miarami i w ten sposób odkrywać zadania i problemy z tego świata się wyłaniające (Langeveld 1983, s. 7-10).

\section{Fenomen atmosfery versus ,tajemnicze oblicze sfinksa”}

Otto Friedrich Bollnow w swych badaniach antropologicznych podjął próbę naświetlania konkretnych, egzystencjalnych doświadczeń, związanych z sytuacjami wychowawczymi (Ablewicz 2003, s. 67-73). Jednym z takich podstawowych doświadczeń jest fenomen atmosfery pedagogicznej. Owa pedagogiczność tworzonej atmosfery opiera się zaś na stosunku zaufania, jaki zachodzi pomiędzy dorosłym i dzieckiem. Zaufanie należy traktować zatem jako warunek konstytuowania się jakościowych wymiarów interakcji wychowawczych. Wraz ze swym zaufaniem dorosły darowuje bowiem dziecku to, co od strony emocjonalnej umożliwia jego rozwój i motywuje je do działania. Dziecko, doświadczając zaufania, chce zdobyć uznanie osoby wychowawczo znaczącej, która obdarzyła je zaufaniem, wyzwalając w ten sposób w sobie dążenia do okazania się godnym zaufania. Relacja wychowawcza oparta na „odwadze zaufania” wyraża się więc w wierze w innego człowieka i jest nieodzownym warunkiem zawiązywania się wspólnoty, która daje dziecku psychologiczne poczucie bezpieczeństwa, tworząc pedagogicznie korzystny klimat (atmosferę) dla jego rozwoju (Bollnow 1989, s. 25, 50, 74). Tym samym pedagogiczną atmosferę (kreowaną przez takie postawy, jak: zaufanie, życzliwość, cierpliwość czy dostępność), dającą o sobie znać szczególnie w sytuacjach interpersonalnych współzależności, traktować należy jako czynnik edukacyjnie sprawczy (Bollnow 1989, s. 5-15). Dzięki tej atmosferze wychowanek buduje swoje własne zaufanie do świata oraz jego zrozumienie (Ablewicz 2003, s. 73). Rozumienie otaczającej rzeczywistości określa zaś egzystencję dziecka, stając się sposobem jego bycia w świecie, który nie jawi się już jako budzące strach "tajemnicze oblicze sfinksa” (Pulkowska 1979, s. 1185, 1187). 
Fenomen obecności versus „piętno kompleksu Edypa”

Werner Loch, zgodnie z rozwijanym przez siebie autobiograficznym badaniem indywidualnych losów człowieka (Krüger 2005, s. 98), dowartościowywał znaczenie form aktywności, których źródłem sprawczym jest sam wychowanek, „odczarowując" $\mathrm{w}$ ten sposób nadreprezentowane znaczenie form aktywności związanych ze sprawczą dominacją dorosłego w pedagogicznych procesach kształcenia. Przyjmując taki punkt widzenia, najważniejszym problemem badawczym okazuje się konkretna świadomość dziecka, dotycząca możliwości własnej sprawczości w dążeniu do czegoś (Meyer-Drawe 1997, s. 160). Owa świadomość i poczucie własnej sprawczości dziecka nie pojawia się jednak niezależnie od sposobu uobecniania się i wpływów osób socjalizująco znaczących. W tym też kontekście autor podjął problem relacji dziecka $\mathrm{z}$ ojcem, odwołując się zarazem do freudowskiego kompleksu Edypa, jako egzemplifikacji mechanizmów rywalizacji i identyfikacji. Zarówno „zła obecność" ojca (np. wzbudzająca fobie i wycofanie dziecka), jak i „nieobecność" ojca nie pozostają bez znaczenia zarówno dla sposobu postrzegania przez dziecko określonych ról społecznych, jak i sposobu ich pełnienia (Loch 1986, s. 66-77). Należy zatem przyjąć, że typ relacji (relacje: neurotyczna lub afirmatywna, oparte na rywalizacji lub wspieraniu) $\mathrm{z}$ „osobami socjalizująco znaczącymi" pozostawia swoje niezatarte ślady w doświadczeniu dziecka oraz wpływa na jego sposób postrzegania siebie samego i dynamikę jego rozwoju osobowego, a także społecznego.

Fenomen tajemnicy versus „statyczny pancerz doświadczenia”

Käte Meyer-Drawe podjęła problem cielesności i socjalizacji w kontekście komunikacyjnych możliwości i ograniczeń porozumiewania się, zakładając zarazem, że pedagogiczna racjonalność form komunikacji musi uwzględniać przedrefleksyjny wymiar responsywności doświadczenia językowego i cielesnego (Lippitz 2005, s. 32-33). Wychodząc z takiej pozycji, koncentrowała się więc na formach symbolicznych (język) i materialnych (ciało), traktując je jako przesłanki w analizowaniu pedagogicznych aspektów dorastania, ujmowanych z perspektywy psychologii rozwojowej. Dziecko w swym konkretnym bycie poddane jest wpływom procesów socjalizacyjnych, doświadczając tym samym swego egzystencjalnego zakorzeniania w świecie. Co więcej, zanim dziecko zacznie odróżniać to, czym jest samo, od tego, co go otacza, posiada już jakieś pierwotne doświadczenie owego wspólnego świata. W tym znaczeniu każde nowe doświadczenie posiada jakiś punkt odniesienia we wcześniejszych doświadczeniach oraz staje się punktem orientacyjnym dla kolejnych doświadczeń, które w sposób wtórny ujęte zostają w aktach rozumienia. Elementem owego pierwotnego doświadczenia jest również doświadczanie asymetryczności relacji z dorosłymi. Asymetryczność ta ustanawia swoistą linię demarkacyjną $\mathrm{w}$ sposobie doświadczania codziennego życia przez dorosłych 
i dzieci. To, w jaki sposób dziecko postrzega otaczający je świat, można bowiem przyrównać do obrazów widzianych w kalejdoskopie, które ukazują się nam w swej rozmaitości i zmienności. Dla dorosłych świat nie jest już jednak kalejdoskopową tajemnicą i łamigłówką, a przypisywane mu znaczenia stają się statyczne. Dorośli nie dostrzegają więc "magicznych wymiarów świata”, tracąc zdolność kalejdoskopowego postrzegania rzeczywistości; postrzegają go przez pryzmat swojego statycznego „pancerza doświadczenia” (Meyer-Drawe 1986, s. 48-55).

Fenomen inności versus „reminiscencja dziecka w nas”

Wilfried Lippitz zakłada, że rehabilitacja przednaukowego doświadczenia świata życia codziennego uwypukla rolę zmysłowo-cielesnych podstaw tegoż doświadczenia, które stanowi medium naszego kontaktu (komunikowania się) ze światem. A zatem proces uczenia się w swej konkretności doświadczania otaczającej rzeczywistości powinien opierać się na zmysłowo przyswajanych umiejętnościach, na których wznoszą się indywidualne możliwości poznawcze człowieka (Lippitz 2005, s. 55-56, s. 269; Meyer-Drawe 1997, s. 160). Sam proces uczenia się, rozumiany jako „otwarty akt komunikacji”, polega na nieustannym konfrontowaniu tego, co oswojone, $\mathrm{z}$ tym, co obce; tego, co utrwalone, $\mathrm{z}$ tym, co nowe (Krüger 2005, s. 101). Tym samym problem odkrywania sposobu doświadczania i przeżywania przez dziecko otaczającego go świata, zakłada, że nie może on być sprowadzony do retrospektywnego odkrywania "dziecka”, którym dorośli sami byli w przeszłości. Rekonstruowanie własnych doświadczeń dzieciństwa i reminiscencje dzieciństwa, zawsze bowiem są pamięcią „świata dziecka” z perspektywy jaźni dorosłego. Reminiscencja „dziecka w nas” nie daje nam zatem rzeczywistego wyobrażenia „dziecka obok nas”. Taka logika analogii jest zawodna, „dziecko obok nas” jest zawsze tym obcym względem „dziecka w nas". W ten sposób relacja dorosłego względem dziecka jest z gruntu etyczna. A cechą „sytuacji etycznej jest heterogeniczność, nie jedność lub wzajemność” (Lippitz 2005, s. 159, 160). Uznanie nieredukowalności podmiotowej struktury dziecka jako innego nakłada więc na „świat dorosłych” etyczne zobowiązanie, aby był zorientowany na „świat dziecka”, poprzez umiejętność przyjmowania jego punktów widzenia, towarzyszenie mu, stwarzanie atmosfery zaufania i współdziałania (Krüger 2005, s. 101-102).

Fenomen wrażliwości versus „naznaczające ślady semiotycznych praktyk”

Max Van Manen podjął badania, w ramach których skoncentrował się na kategoriach holizmu i poetyckości, przy czym sama holistyczność pojawia się tu w nawiązaniu do psychologii humanistycznej i jej sposobu pojmowania ludzkiego życia. Z kolei poetyckość nastawień jest odpowiedzią na bogactwo doświadczeń świata życia codziennego, którego nie da się ująć w unifikujące i obiektywizujące 
„ramy powtarzalności” (Manen 1990, s. 8-13). Doświadczenia poetyckości nie dają się zatem w sposób ścisły zwerbalizować, ponieważ ich werbalne ujęcie oznacza odebranie im tego, co wymyka się zarówno samemu zwerbalizowaniu, jak i próbom obiektywizacji. Doświadczenie takie ukazuje się i staje się udziałem człowieka w inny sposób, można je „słyszeć” tylko w „ciszy” (Meyer-Drawe 1997, s. 160). Holistyczność i poetyckość nastawień implikuje zatem wyeksponowanie rangi wrażliwości, dzięki której przedwerbalnie lub pozawerbalnie ujmowane/ rozważane jest to, co subtelne i niepowtarzalne (Manen 1979, s. 5-16). Taka teoria i praktyka odwołują się tym samym do fenomenu wrażliwości (wyczulenia i wzmożonej uwagi względem tego, co trudno uchwytne) jako jednej z podstawowych przesłanek, która stoi u podstaw nastawień pedagogicznych. Fenomenologiczny wymiar takich nastawień pedagogicznych wyraża się w tym, że dowartościowują one to, co unikalne właśnie, a sama fenomenologia jawi się tu jako „filozofia lub teoria unikalności", ponieważ koncentruje się na tym, co samo w sobie jest niewymienialne i niezastępowalne (Manen 1990, s. 6-7). Z kolei hermeneutyczny wymiar takich nastawień pedagogicznych wyraża się w wyeksponowanie rangi językowej wrażliwości. Przyjąć należy bowiem, że formy językowego wyrazu, jako specyficzne „praktyki semiotyczne” (Manen 1990, s. 111-112), nie tylko umożliwiają zdanie sprawy z tego, co jest i jak jest, ale również, a może przede wszystkim, kreują rzeczywistość poprzez nadawanie znaczeń oraz wymowy temu, do czego się odnoszą i co w sposób językowy ujmują.

\section{Aporetyczna natura doświadczenia rozwoju człowieka}

Rozważając problem ludzkiego rozwoju, można wskazać na pięć podstawowych charakterystyk określających antropologiczne in status nascendi człowieka. Charakterystyki te wytyczają nieredukowalne horyzonty myślenia o człowieku, odsłaniając aporetyczną naturę doświadczenia egzystencjalnego uwarunkowanego samą strukturą doświadczenia świata życia codziennego. Należy stwierdzić zatem, że: 1) człowiek jest bytem określonym faktycznością bycia hic et nunc, ale zarazem jest bytem niedookreślonym w swym teleologicznym horyzoncie istnienia in potentia; 2) człowiek jest swoistą immanencją, ograniczoną realiami granic swoich skończonych możliwości, choć horyzontem jego dążeń jest niemierzalna transcendencja, pozbawiona limitów i ograniczeń; 3) człowiek nigdy nie działa w warunkach idealnych, choć kieruje się jakimiś ideałami i zmierza do stanów wyobrażonych jako idealne; 4) człowiek nie jest sprawcą doskonałym i niezawodnym, choć zobiektywizowane formy jego aktywności i działalności mogą wyrażać się w precyzji, kunszcie i genialności; 5) człowiek nie jest bytem samowystarczalnym ani neutralnym względem świata zewnętrznego, choć może osiągać względną niezależność w obliczu tego, co względem niego samego jest zewnętrznością. 


\section{Aktualność bycia versus potencjalność bycia}

Człowiek jest bytem określonym faktycznością bycia hic et nunc, ale zarazem jest bytem niedookreślonym w swym teleologicznym horyzoncie istnienia in potentia. Zarówno więc to, co aktualne, jak i to, co możliwe nie mogą być postrzegane w kategoriach stałych i niezmiennych, raz na zawsze określonych w swych granicach faktyczności lub potencjalności. Granice tego, co aktualne, i tego, co możliwe, nieustannie ulegają więc przesuwaniu i redefiniowaniu wraz z progresywnym ewoluowaniem egzystencji ludzkiej, która jako taka nieustannie, w sposób aproksymatywny odsłania się i objawia. Akty transgresji ludzkiej rozgrywają się zatem w horyzoncie tego, co możliwe, nie tylko zmieniają strukturę i dynamikę tego, co aktualne, ale również sam horyzont tego, co możliwe.

\section{Immanencja bycia versus transcendencja bycia}

Człowiek jest swoistą immanencją, ograniczoną realiami granic swoich skończonych możliwości, choć horyzontem jego dążeń jest niemierzalna transcendencja, pozbawiona limitów i ograniczeń. Jednym z istotnych paradoksów egzystencji człowieka jest to, że będąc bytem uwarunkowanym i ograniczonym w formach i sposobach swojego bycia, jest zarazem lub może być potencjalnie twórcą dzieł, które nie podlegają już owym uwarunkowaniom i ograniczeniom, a przynajmniej nie w takim stopniu, jak ich twórca, czyli sam człowiek. Człowiek jako byt skończony przy korzystnej konstelacji uwarunkowań biegu swojego życia i odpowiednim stopniu osobistego zdeterminowania nie tylko może sięgać tego, co nieskończone, ale również w nieskończony sposób, w ramach skończoności horyzontu biologicznego życia, może poszerzać i przekraczać granice własnego rozwoju, transcendując siebie samego (aspekt subiektywny transcendowania) oraz świat zastanych możliwości (aspekt obiektywny transcendowania) w aktach transgresji osobistych i historycznych, ekspansywnych i twórczych.

\section{Realność bycia versus horyzont idealności bycia}

Człowiek nigdy nie działa w warunkach idealnych, choć może kierować się jakimiś ideałami i zmierzać do stanów wyobrażonych jako idealne. Życie człowieka zawsze uwarunkowane jest sytuacyjnie, określonym czasem i miejscem, które decydują o jego możliwościach lub ograniczeniach przystosowawczych i rozwojowych. Paradoksem jest jednak to, że wyobrażenie określonych stanów idealnych lub dążenie do pewnych ideałów, jakie przyświecają człowiekowi, może być całkowicie uniezależnione od realnie ustrukturyzowanych możliwości lub ograniczeń, jakich doświadcza człowiek w świecie życia codziennego. Co więcej, możemy mieć do czynienia z sytuacją, w której doświadczanie określonych możliwości lub ograniczeń jest odwrotnie proporcjonalne do stopnia zdeterminowania w dążeniu do 
określonych ideałów lub natężenia i intensywności utożsamiania się z określonymi stanami wyobrażonymi jako idealne.

Niedoskonałość bycia versus doskonałość postaci samoobiektywizacji bycia

Człowiek nie jest sprawcą doskonałym i niezawodnym, choć zobiektywizowane formy jego aktywności i działalności mogą wyrażać się w precyzji, kunszcie i genialności. Człowiek jest istotą, dla której błądzenie i mylenie się jest nieodłączną częścią jego życiowej drogi i rozwoju. Ludzki wymiar istnienia wyraża się więc w stopniowym nabywaniu doświadczeń i uczeniu się tego, jak rozpoznawać właściwą lub niewłaściwą drogę - jak rozpoznawać prawdę i nieprawdę, autentyczność i nieautentyczność, sensowność i bezsensowność, wartościowość i bezwartościowość itd. W tym też znaczeniu strukturami ludzkiego doświadczenia są cyrkularność i aproksymatywność. Niczego, co bezpośrednio wiąże się z rozwojem człowieka, nie osiąga się bowiem od razu i wprost, za jednym razem i na zasadzie pełnego i skończonego aktu creatio ex nihilo.

Nieautonomiczność źródeł bycia versus autonomiczność sposobu bycia

Człowiek nie jest bytem samowystarczalnym ani też nie jest neutralny wobec świata zewnętrznego, choć może osiągać względną autoteliczność w poszczególnych polach swojego doświadczenia i działania. Człowiek nie jest bytem niezależnym od tego, co zewnętrzne, ani też bytem „niewinnym” w swej neutralności i pasywności (izolacji i bierności) względem świata zewnętrznego, choć w sprawczych aktach swojego zindywidualizowanego rozwoju i sposobu bycia może, w mniejszym lub większym stopniu, osiągać względną autonomię w obliczu presji, trendów i racjonalizacji dominujących w świecie zewnętrznym.

\section{Paradoksalność edukacyjnego doświadczenia sensotwórczości}

Świat życia codziennego jako taki, a zatem również odnoszący się do sfery oddziaływań pedagogicznych, to świat zagrożeń i możliwości, świat dialektycznie przenikających się przeciwieństw i aporii; świat zagrożeń w możliwościach i możliwości obecnych w zagrożeniach. To świat doświadczenia, gdzie to, co ograniczone i nieograniczone, materialne i duchowe, zwykłe i niezwykłe, wzajemnie się przenika, ale również w sposób uprzedni określane jest pewną specyficzną, nieredukowalną egzystencjalnie relacją ufundowania. $\mathrm{Z}$ tego punktu widzenia, ujmując tę rzecz w sposób ścisły, należy raczej mówić o tym, co nieograniczone w tym, co ograniczone; o tym, co duchowe w tym, co cielesne; o tym, co niezwykłe w tym, co zwykłe. Rozważmy zatem bliżej kilka z wskazanych relacji fundowania i bycia ufundowanym oraz współzależności stanów rzeczy, które w pierwszym porywie impresji jawią się w naszym doświadczeniu jako proste antynomie. 
To, co nieograniczone (nieskończone) w tym, co ograniczone (skończone)

Wychowanie i kształcenie zawsze pozostają w nieredukowalnym sprzężeniu zwrotnym $z$ doświadczeniem świata życia codziennego (Lyotard 2000, s. 27). Świat ten jest pierwotnie samoistnym i bezwiednym punktem wyjścia oraz punktem odniesienia dla doświadczeń człowieka. Wychowanie i kształcenie zaś może racjonalizować i podtrzymywać uprawomocnienia tego, co zastane lub poddawać to krytycznej rewizji, wykraczając ku temu, co inne. W tym sensie wychowanie i kształcenie nie mogą być wyalienowane i nie mogą alienować ze świata życia codziennego. Dlatego też, aby przyjąć rozumiejącą postawę wobec owego świata codzienności, taką lub inną, trzeba najpierw uznać fakt własnego w nim „zanurzenia”, własnej immanentnej przynależności. W tym znaczeniu nasze zrozumienie siebie samego oraz otaczającego świata jako zadania z natury swej nieskończonego w swych horyzontach poznawczych, ufundowane jest w tym, co ograniczone, gdyż z zasady swej uwarunkowane jest naszym realnym uczestnictwem w czymś oraz faktyczną przynależnością do czegoś. Tak więc nasza przynależność i nasze uczestnictwo jako swoiste ramy, które wytyczają nasze egzystencjalne ograniczenia i limity, zarazem stają się naszym punktem wyjścia, oknem na świat na drodze intelektualnego wykraczania poza własne punkty wyjścia w rozumieniu siebie samego i otaczającego nas świata. Intelektualne wykraczanie jako poszukiwanie rozumienia podąża zaś drogą krytycznego namysłu, wyrażającego się w dystansowaniu, odczarowywaniu i reinterpretowaniu doświadczeń, które w sposób źródłowy były lub są naszym udziałem. Fenomen naszego zanurzenia (przynależności, uczestnictwa) w świat życia codziennego, doświadczanego w sposób intersubiektywny wraz z właściwymi mu przestrzeniami i interwałami czasu, staje się tym samym naszym egzystencjalnie specyficznym i niepowtarzalnym miejscem oraz czasem na drodze podmiotowego wychylania się ku temu, co nieograniczone (nieskończone) w swych horyzontach - osobowego rozwoju i rozumiejącego bycia w świecie. Droga człowieka do nieograniczonego wiedzie więc nie tylko od ograniczonego, ale w skończonym (ograniczonym) bierze swój początek. To, co ograniczone, w znaczeniu negatywnym będąc bowiem prostą antynomią tego, co nieograniczone, jest jednak w tej samej mierze, w sensie pozytywnym, zaczynem i antycypacją tego, co nieograniczone. Transcendentny impuls ku temu, co nieograniczone, pochodzi więc z immanencji tego, co ograniczone.

To, co duchowe (kulturowe) w tym, co materialne (przyrodnicze)

Zakorzenienie człowieka w świecie życia codziennego ma charakter cielesny, ponieważ cielesność jest nieredukowalną postacią naszego bycia w świecie. Ciało, a zatem materialny i przyrodniczy wymiar naszej egzystencji, jest tym, co określa sposób naszego uczestnictwa w świecie, jak i tym, co pierwotnie odróżnia nas od innych obiektów, które zastajemy w tymże świecie. Nie istnieją więc procesy 
intelektualne bez fizjologicznych funkcji mózgu, tak jak nie istnieją też afekty emocjonalne bez fizjologicznych reakcji organizmu ludzkiego. Istnienie człowieka zorganizowane jest bowiem na zasadzie psychofizycznej jedności, ujętej w cielesny kształt. W tym znaczeniu nasze doznania poprzedzają nasze poznanie, lub inaczej rzecz ujmując, nasze reprezentacje poznawcze i intelektualne ufundowane są w naszych zmysłowych impresjach i doznaniach. Władze intelektualne należy uznać zaś za pochodną sfery ludzkiego ducha tak, jak władze zmysłowe - za pochodną konstytucji sfery somatycznej egzystencji człowieka. Podobnie jak receptorami ciała są zmysły, tak, można by rzec, receptorem ducha są władze intelektualne. Dlatego też ludzki duch, paradoksalnie, dopóki nie wyrazi się w samoobiektywizujących działaniach i twórczych dziełach (wytworach materialnych lub symbolicznych intersubiektywnie dostępnych w przestrzeni społecznej i kulturowej), uwarunkowany jest i określany w formach swego przejawiania się ramami cielesności, a zatem determinantami natury przyrodniczej. Treści naszych wrażeń i doznań zmysłowych mogą tym samym otwierać lub zamykać przed nami właściwe horyzonty rozumowania i rozumienia, intelektualnego problematyzowania i kognitywnej racjonalizacji owych wyjściowych, najbardziej pierwotnych źródeł doświadczenia człowieka. $Z$ tego też względu oddziaływania pedagogiczne nie mogą wyrażać się w ignorancji i ambiwalencji co do jakościowych wymiarów treści wrażeń i doznań zmysłowych dziecka (wychowanka, ucznia). Nadto powinny one wyrażać się właśnie w szczególnej dbałości o selektywność treści tychże wrażeń i doznań, upatrując w tym swą własną siłę sprawczą. Z doznań i wrażeń zmysłowo doświadczanej przez dziecko codzienności wychodzą bowiem pierwsze impulsy sposobu postrzegania, rozumienia i oceniania danego w tymże doświadczeniu świata życia codziennego oraz sensów, wokół których świat ten będzie się konstytuować w subiektywnym doświadczeniu wychowanka.

To, co nadzwyczajne (niecodzienne) w tym, co zwyczajne (codzienne)

Oddziaływania pedagogiczne muszą wyrastać z podglebia codzienności, aby ostatecznie torować drogę do przekraczania, choć nie dezawuowania, tego, co codzienne, oswojone, nawykowe. Tylko zanurzenie w realiach owej codzienności daje bowiem podstawy do rzeczywistego doświadczania i rozumienia tego, co posiada różne niedostępne na odległość, bo zazwyczaj nieartykułowane wprost, $\mathrm{w}$ formach intersubiektywnej komunikacji, wymiary. W samym centrum spraw świata życia codziennego niejednokrotnie ważniejsze jest bowiem to, co niewidoczne, niż to, co widoczne; to, co niedopowiedziane, niż to, co wypowiedziane. Takie zrozumienie i stojące $\mathrm{u}$ jego podstaw doświadczenie nie jest więc dostępne z pozycji postronnego obserwatora i odseparowanych murami wnętrz „wieży z kości słoniowej”. Oddziaływania pedagogiczne muszą opierać się na dialektyce doświadczania codzienności i niecodzienności, tożsamości i inności, przywiązania i dystansowania się, aprobaty i krytyki, afirmacji i negacji, konstruowania 
i dekonstruowania, adaptacji i transgresji, reprodukcji i emancypacji, umiaru i radykalności, permisywności i pryncypialności. Niecodzienność efektów oddziaływań pedagogicznych wyłania się tu $\mathrm{z}$ „lędźwi” oswojonej, zrozumianej, a następnie zorientowanej intencjonalnie na przekraczanie samej siebie codzienności. W łonie nie tyle wypartej czy zaprzeczonej, lecz zracjonalizowanej codzienności rodzi się więc niecodzienność nastawień, planów, aktywności, przedsięwzięć czy osiągnięć, nie tylko tych edukacyjnych, ale również, ujmując rzecz szerzej - społecznych, kulturowych, cywilizacyjnych. Niecodzienność nie może zatem wyradzać się ostatecznie z codzienności oraz nie może deprecjonować jej jako swojego egzystencjalnego podglebia. Zalążek transcendencji tego, co niecodzienne, kiełkuje bowiem w immanencji tego, co codzienne. Codzienność rzeczywistości wychowania i kształcenia wyraża się zaś w zwykłych gestach i czynnościach - w uwadze, jaką dorosły okazuje dziecku, w tonie głosu, jaki towarzyszy wychowawcy w jego rozmowie $\mathrm{z}$ wychowankiem, czy też $\mathrm{w}$ atmosferze, w jakiej nauczyciel realizuje lekcje szkolne. I to z tej właśnie codzienności (zwyczajności) interpersonalnej przestrzeni styczności pochodzą te najbardziej fundamentalne i nieredukowalne zarazem impulsy, formujące stosunek człowieka zarówno względem tego, co doświadczane jako faktyczne lub codzienne, jak i tego, co jawi się na horyzoncie jako hipotetyczne lub niecodzienne.

\section{Edukacja jako odyseja - doświadczenie aporii sensu swojskości i zadomowienia}

W ramach analizy obszarów doświadczenia aporetyczności sensu swojskości i zadomowienia wyróżniam figury: 1) tego, co Znane i tego, co Nieznane; 2) tego, co Takie-Samo i tego, co Inne; 3) tego, co Bliskie i tego, co Odległe; 4) tego, co Rodzime i tego, co Obce. Struktura doświadczenia świata życia codziennego opiera się bowiem zarazem na wzajemnym znoszeniu się oraz warunkowaniu się Znanego i Nieznanego, Tego-Samego i Tego-Innego, Bliskiego i Odległego, Rodzimego i Obcego oraz związanych z tym egzystencjalnych nastawień (zorientowań) wyruszania i powracania, oswojenia i uważności, pasywności i aktywności.

Przyjąć należy, że choć to, co Znane, Takie-Samo, Bliskie i Rodzime określa w sensie pozytywnym sensy doświadczenia swojskości i zadomowienia, to jednak, w kategoriach negatywnych, racją istnienia sensu Znanego jest Nieznane, TegoSamego - Inne, Bliskiego - Odległe, a Rodzimego - Obce. Racją istnienia sensów tożsamości Znanego, Takiego-Samego, Bliskiego i Rodzimego jest bowiem nie tylko odróżnienie się od Nieznanego, Innego, Odległego i Obcego, ale również zawieranie i skrywanie w siebie tego, co in abstracto antynomiczne. Domniemane, idealne sensy swojskości i zadomowienia załamują się w horyzoncie rzeczywistości doświadczenia świata życia codziennego. Owe sensy jawią się bowiem jako płynne, uwarunkowane kontekstowo i sytuacyjnie. Świat życia codziennego, jako źródłowa i wyjściowa podstawa (substrat) najbardziej pierwotnego, in crudo i „surowego”, 
tzn. niewyreżyserowanego i niezadekretowanego systemowo, naturalnego i spontanicznego doświadczenia, implikuje i uwidacznia tym samym aporie sensu swojskości i zadomowienia.

Doświadczenie aporii sensu swojskości i zadomowienia ufundowane jest w dualnej naturze człowieka i świata ludzkich spraw. Człowiek przeżywając swoją obecność i uczestnictwo w świecie życia codziennego, doświadcza go więc jako homo duplex. Doświadczane przez człowieka wymiary jakości tego, co Znane, Takie-Samo, Bliskie i Rodzime, oraz tego, co Nieznane, Inne, Odległe i Obce, w tej samej mierze określają jego tożsamość oraz egzystencjalny status bycia-w-świecie jako homo domesticus, oraz jako homo viator. Co więcej, kondycja człowieka jako homo domesticus warunkuje kondycję i horyzonty człowieka jako homo viator. I odwrotnie, kondycja człowieka jako homo viator stoi u podstaw konieczności lub możliwości nieustannego reinterpretowania kondycji człowieka jako homo domesticus. W ten sposób człowiek jako byt dualny, homo duplex, nie tylko doświadcza świata życia codziennego jako nieustannego ujawniania i uobecniania się pogranicza tego, co Znane, Takie-Samo, Bliskie i Rodzime oraz tego, co Nieznane, Inne, Odległe i Obce, ale również jako wzajemnego ich implikowania się - przenikania i warunkowania.

$\mathrm{Z}$ tak rozumianą kondycją człowieka oraz sposobem jego zakorzenienia-wykorzenienia w otaczającym go świecie związane są również inne, współistniejące in abstracto i in concreto, egzystencjalne stany rzeczy, doświadczane jako immanentnie przynależne światu życia codziennego, tj. konieczność i niekonieczność, przewidywalność i nieprzewidywalność, ciągłość i zmiana, cyrkularność i niecyrkularność, jedność i wielość, oczekiwanie i zapomnienie, naturalność i nienaturalość, skupienie i rozproszenie, czy odsłonięcie i zasłonięcie.

Doświadczenie edukacji rozpostarte jest pomiędzy fenomenami wyruszania i powracania, oswojenia i uważności, pasywności i aktywności, i dlatego też jest ono w sposób ścisły związane z problemem aporii sensu swojskości i zadomowienia. W tym znaczeniu, zarówno antropologia, aksjologia, jak i teleologia pedagogiczna, aby nie konstytuowały jednowymiarowych, zacierających złożoność i niejednoznaczność oddziaływań edukacyjnych, muszą zakładać dialektyczne współistnienie fenomenów wyruszania i powracania, oswajania i czujności, pasywności i aktywności. Edukacja jako swoista odyseja doświadczenia aporii sensu swojskości i zadomowienia $\mathrm{w}$ świecie życia codziennego powinna w swych antropologicznych, aksjologicznych i teleologicznych horyzontach nie tylko budować połączenia pomiędzy tym, co Znane, Takie-Samo, Bliskie i Rodzime, a tym, co Nieznane, Inne, Odległe i Obce, ale również odkrywać pierwiastek Znanego w Nieznanym, a Nieznanego w Znanym, Takiego-Samego w Innym, a Innego w Takim-Samym, Bliskiego w Odległym, a Odległego w Bliskim oraz Rodzimego w Obcym, a Obcego w Rodzimym. Powinna też odkrywać sensotwórcze wymiary, tak dla form przystosowania, jak i rozwoju człowieka, egzystencjalnych doświadczeń wyruszania i powracania, oswojenia i uważności, czy pasywności i aktywności. Edukacja, 
trwając w odpowiedzialności względem własnych zobowiązań i wyzwań, nie może więc zacierać świadomości i realności różnych wymiarów rzeczywistości świata ludzkich spraw, dokonując zafałszowań i mistyfikacji - swoistej narracyjnej „sterylizacji”, która pozwala ujmować wszystko jako jednowymiarowe i skończone, a zatem pozbawione horyzontu problematyczności. Przeciwnie, edukacja powinna budzić argumentatywnie ugruntowaną świadomość zarówno tego, co ujmowane jest jako faktyczne, jak i tego, co wyobrażane jest jako hipotetyczne - zastane i możliwe oraz dane i zadane w otwartym horyzoncie świata życia codziennego.

\section{Bibliografia}

Ablewicz K. (2003). Teoretyczne i metodologiczne podstawy pedagogiki antropologicznej. Kraków: Wydawnictwo Uniwersytetu Jagiellońskiego.

Berger P. L., Luckmann T. (200o). Społeczne tworzenie rzeczywistości, tłum. Niżnik J. Warszawa: Wydawnictwo Naukowe PWN.

Bollnow O. F. (1983). Anthropologische Pädagogik. Bern: Haupt.

Bollnow O. F. (1989). The Pedagogical Atmosphere, tłum. van Manen M. „Phenomenology and Pedagogy”, nr 7.

Conrad-Martius H. (1989). Fenomenologia i spekulacja, tłum. Machnacz J. „Roczniki Filozoficzne", t. XXXIV, z. 1, s. 273-287.

Copei F. (1969). Der Fruchtbare Momente im Bildungsprozess. Heidelberg: Quelle \& Mayer.

Depraz N. (2010). Zrozumieć fenomenologię. Konkretna praktyka, tłum. Czarnecka A. Warszawa: Oficyna Naukowa.

Gara J. (2015). Fenomenologiczne inspiracje hermeneutycznego rozjaśniania fenomenu edukacji. „Kwartalnik Pedagogiczny”, nr 2-3, s. 114-144.

Gara J. (2016). Egzystencjalne doświadczenie aporii sensu swojskości i zadomowienia $w$ świecie życia codziennego. W: Melosik Z., Szymański M. J. (red.). Tożsamość $w$ warunkach zmiany społecznej. Warszawa: Wydawnictwo APS.

Gara J. (2017a, w druku). Egzystencjalna problematyzacja poszukiwania, poznawania i tworzenia samego siebie. W: Dudzikowa M., Tanaś M. (red.). Poszukiwanie, poznawanie i tworzenie samego siebie.

Gara J. (2017b, w druku). Husserlowski świat życia codziennego i jego znaczenie edukacyjne, „Studia Edukacyjne”.

Husserl E. (1976). Kryzys nauki europejskiej a transcendentalna fenomenologia, tłum. Szewczyk J. „Studia Filozoficzne”, nr 9, s. 93-121.

Husserl E. (1989). Wykłady z fenomenologii wewnętrznej świadomości czasu, tłum. Sidorek J. Warszawa: PWN.

Husserl E. (1993). Kryzys europejskiego człowieczeństwa a filozofia, tłum. Sidorek J. Warszawa: Fundacja Aletheia.

Husserl E. (2000a). Badania logiczne, t. II, cz. I, tłum. Sidorek J. Warszawa: PWN. Husserl E. (20oob). Badania logiczne, t. II, cz. II, tłum. Sidorek J. Warszawa: PWN. 
Husserl E. (2006). Badania logiczne, t. I, tłum. Sidorek J. Warszawa: PWN.

Husserl E. (2013). Doświadczenie i sad, tłum. Baran B. Warszawa: Fundacja Aletheia. Ingarden R. (1963). Z badań nad filozofia wspótczesną. Warszawa: PWN.

Ingarden R. (1970). Co jest nowego w ostatniej pracy Husserla? „Studia Filozoficzne”, nr 4-5, s. 3-14.

Ingarden R. (1971). U podstaw teorii poznania, cZ. 1. Warszawa: PWN.

Krasnodębski Z., Nellen K. (1993). Wstęp. W: Krasnodębski Z., Nellen K. (red.). Świat przeżywany. Fenomenologia i nauki społeczne. Warszawa: PIW.

Krüger H.-H. (2005). Wprowadzenie w teorie i metody badawcze nauk o wychowaniu, tłum. Sztobryn D. Gdańsk: GWP.

Langeveld M. J. (1983). Reflections on Phenomenology and Pedagogy. „Phenomenology and Pedagogy", $\mathrm{nr}$ 1/1, s. 5-10.

Langeveld M. J. (1984). How Does the Child Experience the World of Things? "Phenomenology and Pedagogy”, nr 2/3, s. 215-223.

Lippitz W. (2005). Różnica i obcość. Studia fenomenologiczne w obrębie nauki o wychowaniu. Murzyn A., tłum. Kraków: Oficyna Wydawnictwo „Impuls.

Loch W. (1986). Possibilities of the Father Role. „Phenomenology and Pedagogy”, nr $4 / 3$, s. 66-77.

Lyotard J. F. (2000). Fenomenologia, tłum. Migasiński J. Warszawa: Wydawnictwo KR. Manen M. van (1979). The phenomenology of pedagogic of observation. „The Canadian Journal of Education", nr 4/1, s. 5-16.

Manen M. van (1990). Researching Live Experience. Human Science for An Action Sensitive Pedagogy. New York: State University of New York Press.

Meyer-Drawe K. (1986). Kaleidoscope of Experiences: The Capability to be Surprised by Children. „Phenomenology and Pedagogy”, nr 4/3, s. 48-55.

Meyer-Drawe K. (1997). Education. W: Embree L. (red.), Encyclopedia of phenomenology. Dordrecht-Boston-London: Kluwer Academic Publishers.

Michalski K. (1998). Heidegger i filozofia współczesna. Warszawa: PIW.

Patočka J. (1986). Świat naturalny jako problem filozoficzny, tłum. Zychowicz J. W: tenże, Świat naturalny i fenomenologia. Kraków: PAT.

Patočka J. (1993). Filozofia kryzysu nauki wedtug Edmunda Husserla i jego koncepcja fenomenologii „świata przeżywanego", tłum. Zychowicz J. W: Krasnodębski Z., Hellen K. (red.). Świat przeżywany. Warszawa: PIW.

Pulkowska M. (1979). Otto Friedrich Bollnow - filozof zaufania do świata. „Znak”, nr 11.

Reinach A. (2005). O fenomenologii. „Fenomenologia”, nr 3, s. 117-138.

Ricoeur R. (1996). Fenomenologia i hermeneutyka: wychodzac od Husserla..., thum. Drwięga M. „Kwartalnik Filozoficzny”, t. XXIV, z. 3, s. 149-181.

Rolewski J. (1999). Husserlowska kategoria a priori świata przeżywanego. W: Czerniak S., Rolewski J. (red.). Studia z filozofii niemieckiej, t. 3: Współczesna fenomenologia niemiecka. Toruń: Wydawnictwo Uniwersytetu Mikołaja Kopernika. 
Rożdżeński R. (1998). Husserl i problem tak zwanej ogólnej naoczności. „Logos i Ethos", nr 1, s. 13-27.

Scheler M. (1975). Postawa fenomenologiczna, tłum. Węgrzecki A. W: Węgrzecki A., Scheler. Warszawa: Wiedza Powszechna.

Schütz A. (1989). Fenomenologia i nauki społeczne. (tłum.) Lachowska D. W: Krasnodębski Z. (red.). Fenomenologia i socjologia. Warszawa: PWN.

Schütz A. (2012). O wielości rzeczywistości. W: tenże, O wielości światów, tłum. Jabłońska B. Kraków: Zakład Wydawniczy „NOMOS”.

Schütz, A. (1966). Studies in phenomenological philosophy, tłum. Gurwitsch A. The Hague: Nijhoff.

Stróżowski W. (1989). O metodzie fenomenologii. W: Perzanowski J. (red.). Jak filozofować, Warszawa: PWN.

Święcicka K. (1983). Husserl. Warszawa: Wiedza Powszechna.

Tarkowska E. (2000). Życie codzienne jako kategoria interdyscyplinarna. W: Dudzikowa M., Czerepniak-Walczak M. (red.). Wychowanie. Pojęcia. Procesy. Konteksty, t. 5. Gdańsk: GWP.

Zaner R. M. (1975). On the Sense of Method in Phenomenology. W: Pivčević E. (red.). Phenomenology and Philosophical Understending, Cambridge-London-New York-Melbourne: Cambridge University Press.

\title{
PHENOMENOLOGICAL CATEGORY OF THE WORLD OF LIFE AS A CONDITION OF THE EXPLICATION OF EDUCATIONAL MEANING
}

\begin{abstract}
The formulated problem is based on the attempt to bring the three essential issues expressed in the three questions and problem perspectives, which belong to them: 1. What are the basic phenomenological rationales for research settings? 2. How is a phenomenological category of the world of life understood? 3 . How does the phenomenological category of the world of life allow for recognition and lighten the meaning of education? Phenomenology of the world of life, which was developed by Edmund Husserl in the last period of his work, is based on the assumption that the lived world is the starting point of humanities and social sciences, which is adequate and impossible to scale down. It is, in fact, a world of common everyday situations and practical action. In this context, I refer to the phenomenon of educational preliminary issues and imponderabilias, and also consider the issues of creativity meanings of paradoxicality experience, aporia approach and dialectical problems of human development. This creates a basis for the recognition of, according to the title, meanings of education as a specific existential experience of Odyssey.
\end{abstract}

Keywords: phenomenology of the world of life, philosophy of education, existential aporias, thinking by paradoxes, education as the Odyssey. 
Jarosław Gara - doktor habilitowany, profesor nadzwyczajny Akademii Pedagogiki Specjalnej im. Marii Grzegorzewskiej, kierownik Zakładu Pedagogiki Ogólnej i Teorii Wychowania; wiceprzewodniczący Komisji ds. Przewodów Doktorskich. Zainteresowania naukowe: wybrane problemy filozofii nauki, filozofii kultury, filozofii człowieka, psychologii osobowości; filozofia wychowania. Aktualne obszary badań: edukacyjne implikacje i implementacje dyskursu fenomenologicznego, egzystencjalnego, hermeneutycznego. Autor monografii: Człowiek i wychowanie (Warszawa 2007), Pedagogiczne implikacje filozofii dialogu (Kraków 2008), Od filozoficznych podstaw wychowania do ejdetycznej filozofi wychowania (Warszawa 2009). Wybrane publikacje: Fenomen epizodów codzienności jako źródło antycypacji przyszłości (Warszawa 2015), Fenomen egzystencjalnych wymiarów myślenia utopijnego (Wrocław 2016), Refleksyjna problematyzacja tego, co filozoficzne w tym, co pedagogiczne oraz o tego, co pedagogiczne w tym, co filozoficzne (Warszawa 2017), Kultura wychowania jako fenomen drogi okrężnej (Białystok 2017). Adres do korespondencji: APS, ul. Szczęśliwicka 40, 02-353 Warszawa; tel. 2258936 oo, wew. 3440. Adres e-mailowy: jgara@aps.edu.pl. 